\title{
KOMPETENSI PEDAGOGIK GURU PAI DALAM MENINGKATKAN MOTIVASI BELAJAR PESERTA DIDIK KELAS XI MA NURUL IKHLAS AMBON
}

\author{
Muslim \\ Program Studi Pendidikan Agama Islam FITK-IAIN Ambon \\ E-mail: muslimdiken05@gmail.com
}

\begin{abstract}
ABSTRAK: Permasalahan dalam penelitian ini adalah bagaimana kompetensi pedagogik guru PAI dalam proses pembelajaran di kelas XI MA Nurul Ikhlas Ambon dan bagaimana motivasi belajar peserta didik di MA Nurul Ikhlas Ambon. Tipe penelitian adalah penelitian deskriptif kualitatif. Penelitian ini dilaksanakan dari tanggal 18 Februari sampai tanggal 18 Maret 2019 di MA Nurul Ikhlas Ambon. Subjek penelitian adalah guru PAI kelas XI, kepala sekolah dan tiga orang peserta didik kelas XI. Instrumen penelitian yang digunakan adalah lembar observasi dan pedoman wawancara. Analisis data menggunakan reduksi data, penyajian data dan penarikan kesimpulan. Hasil penelitian menunjukkan bahwa: 1) kompetensi pedagogik guru PAI dalam proses pembelajaran di kelas XI MA Nurul Ikhlas Ambon yaitu: (a) memberikan pemahaman dalam pembelajaran, (b) membuat silabus dirinci dalam rancangan pembelajaran, (c) membuat RPP agar materi yang disampaikan terarah, (d) melaksanakan pembelajaran berpusat pada tiga arah, (e) menggunakan teknologi agar peserta didik lebih mudah memahami materi, (f) melakukan evaluasi untuk mengetahui kemampuan peserta didik, (g) mengembangkan potensi peserta didik dengan latihan berceramah, (h) memberikan bimbingan mengingatkan peserta didik agar lebih disiplin dan bertanggung jawab. 2) Motivasi belajar peserta didik di kelas MA Nurul Ikhlas Ambon yaitu guru PAI komunikasi, interaksi dan menyampaikan materi dengan sangat baik sehingga peserta didik termotivasi dalam belajar.
\end{abstract}

Kata Kunci: Kompetensi Pedagogik Guru PAI, Motivasi Belajar.

ABSTRACT: Problem of this research is how interest pedagogik teacher PAI in process of study in class XI MA Nurul Ikhlas Ambon and how motivation of educative participant learning in MA Nurul Ikhlas Ambon. Research type is qualitative descriptive research. This research executed from date of 18 Februari until date of 18 Marchs 2019 in MA Nurul Ikhlas Ambon. Research subject is teacher PAI class XI, headmaster and three educative participant of class XI. instrument of Research applied is observation sheet and interview guidance. Data analysis applies reduction of data, presentation of data and conclusion withdrawal. Result of research indicates that: 1) interest pedagogik teacher $P A I$ in process of study in class XI MA Nurul Ikhlas Ambon that is: ( a) gives understanding in study, (b) makes syllabus detailed in study planning, (c) makes RPP that matter submitted directional, (d) executes study of centre on three directions, (e) applies technology that educative participant easier to comprehend matter, ( $f$ ) does evaluation to know ability of educative participant, $(g)$ develops educative participant potency with discourse practice, (h) gives tuition to remind educative participant that more disciplinely and responsible. 2) motivation of Educative participant learning in class MA Nurul Ikhlas Ambon that is teacher PAl communications, interaction and submits matter excellently so that educative participant motivated in learning.

Keyword: Interest Pedagogik Teacher PAl, Motivation of Learning. 


\section{PENDAHULUAN}

Pendidikan Islam adalah sistem pendidikan yang dapat memberi seseorang untuk memimpin kehidupannya sesuai dengan cita-cita Islam, karena nilai-nilai Islam telah menjiwai dan mewarnai corak kepribadiannya. ${ }^{1}$ Manusia dilahirkan dengan membawa potensi yang dapat dididik dan mendidik sehingga dapat menjadi khalifah di bumi, maka pendidikan Islam merupakan kebutuhan manusia. Pendidikan agama Islam tidak hanya dilaksanakan di lingkungan keluarga dan masyarakat tetapi juga di lingkungan sekolah. Untuk meningkatkan kualitas pendidikan agama Islam pemerintah sudah melaksanakan berbagai kebijakan sehingga diharapkan dapat memberikan nuansa baru bagi sistem pengembangan pendidikan di Indonesia.

Dalam setiap pendidikan formal pada jenjang pendidikan dasar dan menengah, guru merupakan sentral pelaksanaan kurikulum. Guru yang harus lebih mengenal, memahami, dan melaksanakan hal-hal yang tertuang dalam kurikulum. Tanpa guru kurikulum hanyalah benda mati yang tiada arti. $^{2}$ Guru atau pendidik adalah unsur manusiawi dalam pendidikan. Guru adalah figur manusia sumber yang menempati posisi dan memegang peranan penting dalam pendidikan. Undang-undang Nomor 14 Tahun 2005 tentang guru dan dosen menyebutkan bahwa guru adalah pendidik profesional dengan tugas utama mendidik, mengajar, membimbing, mengarahkan, melatih, menilai dan mengevaluasi peserta didik pada pendidikan anak usia dini jalur pendidikan formal, pendidikan dasar dan pendidikan menengah. ${ }^{3}$ Untuk itu, guru dituntut memiliki kemampuan-kemampuan dalam mengajar. Menurut Kementrian Pendidikan dan Kebudayaan, kemampuan guru dibagi dalam empat dimensi yaitu kemampuan pedagogik, kemampuan profesional, kemampuan sosial dan kemampuan kepribadian. Kemampuan profesional harus mendapat perhatian lebih, sebab kemampuan ini akan berkaitan dengan keahlian sebagai pendidik. 
Kompetensi pedagogik guru meliputi kemampuan menjelajah ilmu pengetahuan, menunjukkan keterampilan dalam mengajar dan menampilkan sikap positif terhadap keseluruhan tugasnya sebagai guru. Peran guru sebagai figur sentral dalam proses pembelajaran tidak lepas dari kemampuan pedagogik yang melekat pada dirinya. Kemampuan pedagogik guru secara langsung mempunyai pengaruh yang sangat besar terhadap proses belajar mengajar. Jika guru bisa menyampaikan pelajaran sesuai dengan harapan peserta didik maka akan membuat proses pembelajaran tersebut berjalan dengan efektif dan efisien. ${ }^{4}$

Dalam Undang - Undang Republik Indonesia Nomor 14 Tahun 2005 Tentang Guru dan Dosen disebutkan bahwa "Guru wajib memiliki kualifikasi akademik, kompetensi, sertifikat pendidik, sehat jasmani dan rohani, serta memiliki kemampuan untuk mewujudkan tujuan pendidikan nasional". Kompetensi yang harus dimiliki oleh guru dijelaskan secara lebih detail dalam peraturan Menteri Pendidikan Nasional Republik Indonesia Nomor 16 Tahun 2007 Tentang Standar Kualifikasi Akademik dan Kompetensi Guru. Dalam peraturan tersebut disebutkan bahwa ada 4 kompetensi utama yang harus dimiliki oleh guru, yaitu kompetensi pedagogik, kompetensi kepribadian, kompetensi sosial dan kompetensi profesional. Keempat kompetensi tersebut terintegrasi dalam kinerja guru. ${ }^{5}$

Bertolak dari uraian di atas, dapat dikatakan bahwa setiap guru di negara Indonesia dituntut untuk memiliki kemampuan atau kompetensi yang mumpuni. Dengan kompetensi tersebut guru dapat menjalankan tugas pendidikan dengan baik, terutama dalam proses pembelajaran sesuai dengan prosedur yang tersusun dalam manajemen pendidikan yang dimulai dengan perencanaan yang matang sesuai dengan kebutuhan peserta didik, kemudian dilaksanakan dalam proses pembelajaran yang efektif dan menyenangkan sampai terlaksananya evaluasi dan hasilnya sesuai dengan tujuan yang tertuang dalam rencana 
pelaksanaan pembelajaran. Jika ini terjadi, maka dengan sendirinya akan muncul motivasi belajar yang aktif dari peserta didik.

Motivasi belajar adalah merupakan faktor psikis yang bersifat nonintelektual. Pada saat proses pembelajaran berlangsung, guru sebagai seorang motivator melaksanakan tugas dan tanggung jawabnya agar peserta didik dapat termotivasi dalam proses pembelajaran yang diberikan. ${ }^{6}$

Berdasarkan observasi yang peneliti lakukan di lokasi penelitian, peneliti melihat banyaknya faktor yang harus diperhatikan oleh peserta didik dalam meningkatkan hasil belajar mereka pada mata pelajaran PAI. Selain itu, guru diharuskan untuk senantiasa memperhatikan motivasi belajar peserta didik. Kondisi pembelajaran PAI di MA Nurul Ikhlas Ambon, bisa dikatakan kurang memberikan kontribusi positif bagi peserta didik dalam memahami konsep agama dalam kehidupan sehari-hari. Hal ini dilihat proses pembelajaran yang hanya mengandalkan evaluasi dan pemberian tugas kepada peserta didik dalam setiap proses pembelajaran PAI. Guru dinilai kurang aktif dalam mengontrol peserta didik untuk mengerjakan pekerjaan rumahnya atau disiplin dalam mengikuti proses pembelajaran. Dalam pembelajaran, peserta didik terlihat ada yang malas mengikuti pelajaran PAI atau malas melaksanakan tugas PR PAI di rumah. $^{7}$

Selain hasil observasi yang peneliti lakukan di atas, maka peneliti melakukan wawancara dan bersifat awal dengan kurikulum MA Nurul Ikhlas Ambon yang menuturkan bahwa guru di sekolah tersebut berjumlah 22 orang dan guru PAI berjumlah 2 orang. Namun kompetensi pedagogik yang dimiliki oleh tiap guru berbeda-beda. Sebagian besar dari mereka dalam melaksanakan pembelajaran tampak biasa saja dan kurang akan aspek pedagogik sehingga peserta didik merasa bosan dan tidak mengembangkan potensi yang dimilikinya. Hal ini berdampak pada motivasi belajar peserta didik dalam mengikuti pelajaran sehingga tujuan dari pendidikan tidak tercapai. Terlebih lagi peserta didik tidak akan 
mengaktualisasikan nilai dari pelajaran yang disampaikan guru, khususnya pada mata pelajaran Pendidikan Agama Islam. Selain itu yang peneliti amati terlihat bahwa tugas dan tanggung jawab guru PAI di MA Nurul Ikhlas Ambon hanya sebatas sebagai pengajar di ruang kelas, dan membiarkan peserta didiknya berkembang sendiri sehingga berpengaruh pada keberhasilan mereka dalam proses pembelajaran. Tanpa disadari motivasi belajar PAI sangat berpengaruh pada hasil belajar peserta didik. ${ }^{8}$

Merujuk pada uraian tersebut sekiranya motivasi berfungsi sebagai pendorong usaha dan pencapaian prestasi. Adanya motivasi yang baik dalam belajar akan menunjukkan hasil yang baik, dengan adanya usaha yang tekun dan didasari adanya motivasi, maka seseorang yang belajar akan dapat melahirkan prestasi yang baik. Intensitas motivasi peserta didik akan sangat menentukan tingkat pencapaian prestasi belajarnya, agar peserta didik memiliki motivasi dalam belajar, maka guru memiliki peranan yang sangat penting. Guru tidak hanya menerangkan, melatih, memberi ceramah, tetapi juga mendesain materi pelajaran, membuat pekerjaan rumah, mengevaluasi prestasi peserta didik, dan mengatur kedisiplinan, maka peranan guru sangat dibutuhkan agar proses pembelajaran PAI sangat mempengaruhi keberhasilan peserta didik dalam proses pembelajaran di MA Nurul Ikhlas Ambon Kecamatan Sirimau Ambon.

Berdasarkan problem tersebut, penulis tertarik untuk meneliti lebih lanjut tentang kompetensi guru dalam melaksanakan pembelajaran PAI dan hubungannya dengan motivasi belajar peserta didik dalam pembelajaran tersebut dengan judul "Kompetensi Pedagogik Guru PAI Dalam Meningkatkan Motivasi Belajar Peserta Didik kelas XI MA Nurul Ikhlas Ambon Kecamatan Sirimau Ambon". Mengingat permasalahan tentang kompetensi guru sangat luas, maka penelitian ini dibatasi pada fokus permasalahan tentang kompetensi pedagogik guru PAI dalam meningkatkan motivasi belajar peserta didik kelas XI MA Nurul Ikhlas Ambon Kecamatan Sirimau Ambon. Dengan demikian, maka yang 
menjadi permasalahan dalam penelitian ini antara lain: 1. Bagaimana kompetensi pedagogik guru PAI dalam memotivasi pembelajaran di kelas XI MA Nurul Ikhlas Ambon Kecamatan Sirimau Ambon? dan 2. Bagaimana motivasi belajar peserta didik kelas XI di MA Nurul Ikhlas Ambon Kecamatan Sirimau Ambon?

\section{METODE PENELITIAN}

\section{Jenis Penelitian}

Jenis penelitian ini yaitu jenis penelitian kualitatif yang temuantemuannya diperoleh melalui pemahaman secara mendalam terhadap suatu masalah. Jenis penelitian ini termasuk jenis penelitian lapangan, data-data yang dipakai bersumber pada hasil penelitian di lapangan. Data yang dihasilkan dari penelitian di lapangan menjadi bahan primer. Selain itu, dalam penulisan ini, penulis juga menggunakan bahan sekunder. Bahan sekunder berupa buku-buku yang terkait dengan pendidikan, serta pedagogik guru dalam proses pembelajaran, serta sumber tulisan lainnya yang terkait dengan permasalahan yang dikaji di dalam penelitian ini. ${ }^{9}$

\section{Sifat Penelitian}

Penelitian ini bersifat deskriptif-analisis yaitu mengumpulkan datadata yang berkaitan dengan penelitian kemudian memaparkan data-data tersebut dan selanjutnya dianalisis secara kualitatif dengan menggunakan teori yang sudah ada.

\section{Waktu dan Tempat Penelitian}

Penelitian ini dilaksanakan selama satu bulan terhitung mulai dari tanggal 18 Februari sampai dengan 18 Maret 2019. Penelitian ini bertempat di MA Nurul Ikhlas Ambon Kecamatan Sirimau Ambon.

\section{Prosedur Pengumpulan Data}

Untuk memperoleh data dari lapangan dalam penelitian ini, peneliti menggunakan metode-metode penggalian data sebagai berikut:

Metode observasi ini digunakan peneliti guna mengumpulkan data melalui pengamatan langsung atau peninjauan secara cermat di lapangan atau lokasi penelitian untuk melihat proses pembelajaran. 
Metode wawancara yang digunakan oleh peneliti untuk mendapatkan informasi dengan berkomunikasi langsung dengan nara sumber yaitu kepala sekolah, guru PAI, dan tiga orang peserta didik kelas XI di MA Nurul Ikhlas Ambon untuk mengetahui tentang kompetensi pedagogik guru PAI yang dilaksanakan secara terstruktur dimana peneliti telah menyiapkan daftar pertanyaan kepada informan dengan jenis pertanyaan yang sama persis kepada mereka semua.$^{10}$

Metode dokumentasi yang digunakan peneliti adalah pengumpulan data dari data-data yang telah didokumentasikan dalam berbagai bentuk. Metode dokumentasi adalah mencari data mengenai hal-hal atau variabel yang berupa catatan, transkrip, buku, surat kabar, notulen rapat, agenda dan lain sebagainya".

\section{Teknik Analisis Data}

Data dari penelitian ini akan dianalisis secara deskriptif kualitatif, proses analisa data dimulai dari seluruh data yang diperoleh dari sumber observasi, wawancara, dan dokumentasi.

Analisis data kualitatif adalah bersifat induktif, yaitu suatu analisis berdasarkan data yang diperoleh dari hasil wawancara dengan cara mengorganisasikan data ke dalam kategori, menjabarkan ke dalam unitunit, melakukan sintesis, menyusun ke dalam pola, memilih mana yang penting dan yang akan dipelajari, dan membuat kesimpulan sehingga mudah dipahami oleh diri sendiri maupun orang lain. Dalam menganalisis data, dilakukan melalui 3 tahapan yaitu: ${ }^{11}$

\section{a. Reduksi Data}

Data yang diperoleh dari lapangan jumlahnya cukup banyak, untuk itu maka perlu dicatat secara teliti dan rinci. Mereduksi data berarti merangkum, memilih hal-hal yang pokok, memfokuskan pada hal-hal yang penting, dicari tema dan polanya dan membuang yang tidak perlu. Dengan demikian data yang telah direduksi akan memberikan gambaran yang lebih jelas, dan mempermudah peneliti untuk melakukan 
pengumpulan data selanjutnya. Adapun tahap pereduksian tersebut melalui beberapa proses yaitu:

a. Proses pemilihan.

b. Pemusatan perhatian pada proses penyederhanaan.

c. Pengabstraksian data mentah atau data kasar yang ada dalam catatan penulis.

\section{b. Penyajian Data}

Setelah data direduksi, langkah selanjutnya adalah menyajikan data. Penyajian data bisa dilakukan dalam bentuk uraian singkat, bagan, hubungan antar kategori dan sejenisnya. Namun yang paling sering digunakan untuk menyajikan data dalam penelitian kualitatif adalah dengan teks yang bersifat naratif.

\section{c. Penarikan kesimpulan}

Kesimpulan awal yang dikemukakan berupa fakta berdasarkan hasil penelitian yang diperoleh saat penelitian berlangsung yang mendukung pada tahap pengumpulan data selanjutnya. ${ }^{12}$

\section{Tahap - Tahap Penelitian}

Tahap-tahap dalam penelitian ini adalah:

1. Peneliti melakukan observasi untuk mengetahui kondisi objektif pada lokasi penelitian.

2. Peneliti melakukan wawancara untuk mengetahui komentar responden yaitu peserta didik MA Nurul Ikhlas Ambon.

3. Studi dokumentasi, pada tahap ini peneliti mengumpulkan hasilhasil penelitian untuk dianalisis dan bukti-bukti penelitian meliputi surat penelitian dan lain-lain.

\section{PEMBAHASAN}

1. Kompetensi Pedagogik Guru PAl Dalam Meningkatkan Motivasi Belajar Peserta Didik MA Nurul Ikhlas Ambon

\section{a. Pemahaman Terhadap Peserta Didik}


Berdasarkan hasil wawancara dengan kepala sekolah, guru PAI dan peserta didik MA Nurul Ikhlas Ambon, dapat disimpulkan bahwa, guru PAI dalam memberikan pemahaman terhadap peserta didik saat proses pembelajaran sudah melakukannya dengan sangat baik, hal tersebut di lihat dari sebelum masuk pada materi guru PAI buka dengan apersepsi dan menanyakan materi sebelumnya serta memberikan gambaran terlebih dahulu dengan bahasa yang mudah agar peserta didik dapat memahami materi yang akan dibahas hal ini disesuaikan dengan karakter peserta didik karena masing-masing peserta didik berbeda kemampuan.

Memandangkan kedudukan guru itu sangat mulia, maka sewajarnya mereka dihormati dan dikenang jasanya sepanjang hayat. Para sahabat dan salaf Al - soleh merupakan suri tauladan umat manusia yang telah memberikan banyak contoh dalam menghormati seorang guru. Rasulullah sallallahualaihi wasallam bersabda; Artinya: Tidak termasuk golongan kami orang yang tidak memuliakan yang lebih tua dan menyayangi yang lebih muda serta yang tidak mengerti (hak) orang yang berilmu (agar diutamakan pandangannya)." (Riwayat Ahmad). ${ }^{13}$

Dari hadits dapat dipahami bahwa tanggung jawab merupakan kewajiban individu sebagai hamba Allah yang kepadanya dititipkan amanat untuk menjadi pemimpin atau penguasa (termasuk guru), baik pemimpin dirinya sendiri maupun pemimpin terhadap apa dan siapapun yang menjadi tanggung jawabnya. Sebagaimana firman Allah dalam surat al-Nahl ayat 43;

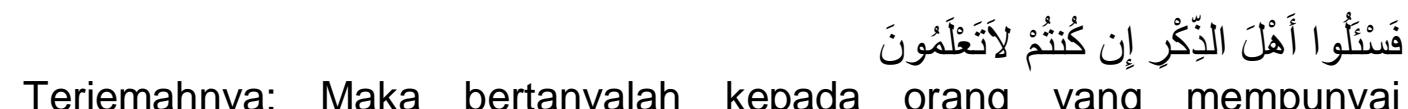
pengetahuan jika kamu tidak mengetahui. ${ }^{14}$

Bertanyalah kepada para ulama, begitulah pesan Allah di ayat dengan bertanya maka akan hilang kebodohan, hilang keraguan, serta mendapat keilmuan.Tidak diragukan bahwa bertanya juga mempunyai adab di dalam Islam. Para ulama telah menjelaskan tentang adab bertanya ini. Mereka mengajarkan bahwa pertanyaan harus disampaikan 
dengan tenang, penuh kelembutan, jelas, singkat dan padat, juga tidak menanyakan pertanyaan yang sudah diketahui jawabannya. Karena itu sebagai orang yang mengemban amanat profesi mulia, seorang guru yang adalah Pemimpin dan sekaligus pelayan bagi peserta didiknya itu memiliki kewajiban untuk memimpin dan melayani peserta didiknya dengan sebaik-baiknya, karena pada saatnya akan diminta pertanggung jawaban atas kepemimpinannya tersebut. Guru atau pendidik sebagai orang tua kedua dan sekaligus penanggung jawab pendidikan anak didiknya harus bertanggung jawab atas sikap, tingkah laku, dan perbuatan anak didiknya. ${ }^{15}$

Dari uraian di atas, maka dapat dikatakan bahwa kompetensi pedagogik atau kemampuan guru dalam pengelolaan pembelajaran peserta didik guru juga harus meliputi kemampuan menjelajah ilmu pengetahuan, menunjukkan ketrampilan dalam mengajar dan menampilkan sikap positif terhadap keseluruhan tugasnya sebagai guru. Peran guru sebagai figur sentral dalam proses pembelajaran tidak lepas dari kemampuan pedagogik yang melekat pada dirinya. Jika guru bisa menyampaikan pelajaran sesuai dengan harapan siswa maka akan membuat proses pembelajaran tersebut berjalan dengan efektif dan efisien.

\section{b. Pengembangan Kurikulum dan Silabus}

Berdasarkan hasil wawancara dengan guru PAI dan kepala sekolah MA Nurul Ikhlas Ambon, bahwa untuk mengembangkan kurikulum/silabus, guru PAI mengacu pada standar isi K13 kemudian dibuat dalam silabus dan rincikan dalam rencana pengembangan pembelajaran (RPP). Hal ini sesuai dengan pendapat Mulyasa, Pengembangan KTSP perlu didukung oleh iklim pembelajaran yang kondusif bagi terciptanya suasana yang aman, nyaman dan tertib, sehingga proses pembelajaran dapat berlangsung dengan tenang dan menyenangkan. ${ }^{16}$ Guru PAI merancang pembelajaran sudah melakukannya dengan cukup baik, dimana guru telah menerapkan teori belajar dan pembelajarannya di dalam merancang 
rancangan pembelajaran seperti pada RPP, silabus, serta penerapan pembelajarannya sesuai dengan rancangan pembelajaran yang telah dibuat serta mencari informasi-informasi baru lewat internet terkait dengan kompetensi pedagogik dalam pengembangan kurikulum dan silabus.

\section{c. Perancangan Pembelajaran}

Berdasarkan hasil wawancara dengan guru PAI dan kepala sekolah, bahwa rancangan pembelajaran yang dibuat guru MA Nurul Ikhlas Ambon sudah baik, guru PAI sebelum menyampaikan materi di kelas yaitu harus mempersiapkan buku pelajaran, membuat RPP dan silabus supaya materi yang akan disampaikan terarah dan materi yang disampaikan terstruktur sesuai dengan rancangan pembelajaran yang dibuat (RPP) sehingga dengan mudah peserta didik paham dengan apa yang disampaikan dan tujuan yang diharapkan dapat tercapai. Berdasarkan hasil pengamatan peneliti guru PAI saat masuk kelas tidak membawa perangkat pembelajaran namun hasil wawancara dengan guru yang bersangkutan menyatakan bahwa sebelum melaksanakan pembelajaran terlebih dahulu sudah membuat perangkat pembelajaran agar materi yang disampaikan terarah, kesimpulan dari peneliti bahwa guru PAI telah menguasai bahan ajar yang dibuat.

Sesuai dengan yang dikatakan Mulyasa, Rancangan Pembelajaran merupakan upaya untuk memperkirakan tindakan yang akan dilakukan dalam kegiatan pembelajaran. Kompetensi dasar berfungsi mengembangkan potensi peserta didik, materi standar berfungsi memberi makna terhadap kompetensi dasar, indikator hasil belajar berfungsi menunjukan keberhasilan pembentukan kompetensi peserta didik. ${ }^{17}$

\section{d. Pelaksanaan Pembelajaran}

Dari hasil wawancara dengan Guru PAI ternyata Kemampuan guru dalam melaksanakan pembelajaran guru berupaya mengembangkan pembelajaran berpusat pada peserta didik dan berjalan tiga arah yaitu guru ke peserta didik, peserta didik ke guru dan peserta didik ke peserta didik. Metode yang digunakan seperti ceramah, tanya jawab, demonstrasi 
dan simulasi. Menurut peneliti guru PAI hal tersebut masih kurang akan aspek pedagogik namun berdasarkan hasil observasi peneliti materi yang diajarkan tetap dipahami dengan baik. Guru PAI melaksanakan proses pembelajaran di kelas dengan sangat baik, karena selain guru PAI memberikan pelajaran guru PAI juga memberikan arahan-arahan berupa nasehat serta memberikan pertanyaan dari materi yang diajarkan, memberikan kesempatan untuk bertanya terkait hal-hal yang belum mengerti, menanyakan materi yang disampaikan sudah paham atau belum serta mengevaluasi peserta didik dalam proses pembelajaran. Guru adalah figur manusia sumber yang menempati posisi dan memegang peranan penting dalam pendidikan. Undang-undang Nomor 14 Tahun 2005 tentang guru dan dosen menyebutkan bahwa guru adalah pendidik profesional dengan tugas utama mendidik, mengajar, membimbing, mengarahkan, melatih, menilai dan mengevaluasi peserta didik. ${ }^{18}$

\section{e. Pemanfaatan Teknologi Pembelajaran}

Dari hasil wawancara dengan Guru PAI, Kepala Sekolah, dan peserta didik MA Nurul Ikhlas Ambon. Dapat disimpulkan bahwa teknologi dalam pembelajaran sangat dibutuhkan di MA Nurul Ikhlas Ambon. Dengan penggunaan teknologi peserta didik lebih mudah memahami materi yang disampaikan guru dan kegiatan pembelajaran jadi lebih menarik dan mempermudah proses pembelajaran sehingga peserta didik lebih memusatkan perhatiannya pada materi yang disampaikan dan peserta didik tidak merasa bosan dalam mengikuti pembelajaran dan pembelajaran lebih menarik suasana kelas tidak monoton dan membuat suasana kelas menjadi hidup. Berdasarkan hasil wawancara guru PAI tidak sering menggunakan teknologi dalam pembelajaran karena fasilitas sekolah masih sangat terbatas. Walaupun fasilitas sekolah masih sangat terbatas tetapi guru sering kali menggunakan laptop dan infokus dengan tujuan memudahkan proses pembelajaran. Dari hasil observasi peneliti saat berada di lokasi penelitian terlihat bahwa guru PAl tidak menggunakan alat pembelajaran lain seperti media gambar dan lain 
sebagainya jadi, kesimpulan peneliti hal tersebut masih kurang akan aspek pedagogik.

Hal ini seperti apa yang dikatakan oleh Dewi Salma, penggunaan teknologi informasi sebagai media pembelajaran dan teknologi informasi sebagai sumber belajar dan pembelajaran. ${ }^{19}$ Abdul Majid \& Dian Andayani, pemanfaatan teknologi informasi dan komunikasi adalah untuk mendapatkan informasi-informasi terbaru dalam rangka mencari gagasan untuk pembuatan benda-benda keterampilan sebagai wujud dari kreatifitas peserta didik. ${ }^{20}$

\section{f. Evaluasi Pembelajaran}

Dari hasil wawancara dengan Guru PAI, Kepala Sekolah dan peserta didik MA Nurul Ikhlas Ambon. Dapat disimpulkan bahwa penilaian merupakan salah satu tugas utama guru karena dengan penilaian guru dapat mengukur tingkat daya serap peserta didik terhadap materi yang diajarkan. Dalam proses pembelajaran seorang guru harus selalu melakukan evaluasi karena sangat penting untuk mengetahui kemampuan peserta didik.

Hal ini seperti yang dijelaskan oleh Novan Ardy Wiyani, olehnya itu ada beberapa jenis evaluasi sebagai berikut: a. Evaluasi formatif, yaitu evaluasi pembelajaran yang dilaksanakan setiap peserta didik selesai mempelajari beberapa kompetensi dasar (KD) yang harus dicapai pada mata pelajaran tertentu di satu pokok bahasan mata pelajaran tersebut. b. Evaluasi sumatif, yaitu evaluasi yang dilaksanakan setiap pertengahan dan akhir pembelajaran. c. Evaluasi diagnostik, yaitu evaluasi yang dilaksanakan sebagai sarana untuk mendiagnosis berbagai kendala dalam proses pembelajaran. d. Evaluasi penempatan, yaitu evaluasi pembelajaran yang dilaksanakan untuk menempatkan peserta didik dalam suatu program pendidikan atau jurusan yang sesuai dengan kemampuan (baik potensi, maupun aktual) dan minat peserta didik. ${ }^{21}$ 


\section{g. Pengembangan Potensi Peserta Didik}

Dari hasil wawancara dengan Guru PAI, kepala sekolah dan peserta didik MA Nurul Ikhlas Ambon. Dapat disimpulkan bahwa untuk mengembangkan potensi peserta didik salah satu yang dilakukan guru PAl adalah praktek ceramah atau tauhid dengan langkah itu guru PAI tidak lupa memberikan motivasi dan membimbing mereka dalam belajar, memberikan pujian saat praktek, dan juga memberikan bimbingan atau cara-cara berceramah agar mereka paham, disamping itu guru juga menanamkan rasa percaya diri untuk tidak malu ketika tampil di depan kelas, memberikan motivasi, memberikan pujian agar mereka merasa senang. Hal ini seperti apa yang dikatakan Kumandar, memberikan pembelajaran pengayaan pada hakikatnya adalah pemberi bantuan bagi peserta didik yang memiliki kemampuan lebih, baik dalam kecepatan maupun kualitas belajar. ${ }^{22}$

\section{h. Bimbingan Konseling}

Dari hasil wawancara dengan kepala sekolah, pesrta didik dan Guru MA Nurul Ikhlas Ambon. Dapat disimpulkan bahwa sebagai guru PAI selalu menginggatkan peserta didiknya supaya lebih rajin disiplin untuk masuk sekolah pada waktu yang sudah ditentukan (tepat waktu), disiplin dalam berpakaian, sebelum masuk kelas ruangan sudah bersihkan, rajin kerjakan tugas, baca doa sebelum belajar dan lebih penting lagi mengerjakan sholat dapat bertanggung jawab. Hal ini seperti yang di katakan Kumandar, bimbingan dan konseling adalah proses bantuan kepada peserta didik agar dapat memahami norma, aturan, atau adat yang dijunjung tinggi di lingkungan keluarga, sekolah, masyarakat, dan mampu menyesuaikan diri terhadap norma tersebut secara positif dan konstruktif. $^{23}$

\section{Motivasi belajar peserta didik kelas XI di MA Nurul Ikhlas Ambon Kecamatan Sirimau Ambon}

Berdasarkan hasil wawancara yang diperoleh dapat disimpulkan bahwa guru PAI menyampaikan materi dengan sangat baik, berinteraksi 
dengan peserta didik dalam pembelajaran, guru PAI juga mengajarkan hal-hal yang baik agar peserta didik selalu disiplin dalam hal berupa apapun dan selalu memberikan motivasi untuk belajar baik di dalam maupun di luar jam pelajaran, maka dari itu peserta didik merasa termotivasi untuk belajar. Berdasarkan hasil observasi peneliti melihat bahwa peserta didik SMS selalu datang tepat waktu dan adapun yang datang terlambat hanya beberapa orang saja, lebih khusus peserta didik pada jam PAI peneliti melihat bahwa apa bila sudah jam masuk sebelum guru masuk di kelas semua peserta didik sudah di dalam kelas dan menunggu guru yang bersangkutan untuk menerima materi.

Hal ini seperti yang disampaikan oleh kaum konstruktif, belajar merupakan proses aktif mengkonstruksi arti entah teks, dialog, pengalaman fisik, dan lain-lain. Belajar juga merupakan proses mengasimilasikan dan menghubungkan pengalaman atau bahan yang dipelajari dengan pengertian yang sudah dipunyai seseorang sehingga pengertiannya dikembangkan. ${ }^{24}$ Belajar adalah suatu proses perubahan tingkah laku melalui interaksi antara individu dan lingkungan. ${ }^{25}$ Proses belajar ditandai oleh adanya perubahan pada perilaku individu, tetapi tidak semua perubahan pada perilaku individu terjadi karena belajar. ${ }^{26}$

Berdasarkan hasil wawancara yang diperoleh dapat disimpulkan bahwa guru PAI selalu memberikan pemahaman pentingnya ilmu agama bagi kehidupan, guru PAI selalu menanamkan kesadaran kepada peserta didik untuk selalu mengerjakan tugas dari guru, apa bila diberikan tugas untuk berdiskusi peserta didik mereka belajar dengan giat agar tampil dengan hasil yang baik ataupun tugas lainnya dantugas yang sudah dikerjakan dikumpul kemudian dikembalikan benar atau salah guru PAI selalu memotivasi mereka agar lebih baik lagi seperti memberikan komentar baik lisan yang berupa kata-kata yang dapat memotivasi mereka dan untuk komentar tulisan hanya berupa benar salah. Berdasarkan hasil observasi peneliti melihat bahwa pada hari itu peserta didik sedang berdiskusi mereka terlihat aktif sekali dan dibimbing langsung oleh guru 
yang bersangkutan, suasana kelas hari itu sangat ramai sampai diskusi selesai karena masing-masing menyampaikan pendapatnya.

Berdasarkan hasil wawancara dengan guru PAI dan keterangan yang diberikan oleh peserta didik tentang motivasi belajar di kelas yang diberikan guru PAI terhadap peserta didik dapat disimpulkan bahwa, melakukan komunikasi dengan baik terhadap peserta didik sehingga ada interaksi antara guru dan peserta didik dalam pembelajaran. Berdasarkan hasil observasi, peneliti melihat motivasi belajar peserta didik saat pembelajaran, peserta didik sangat aktif dalam merespon pertanyaan dari guru dan pendapat dari teman serta saling bertukar pendapat dan mengeluarkan ide-ide atau gagasan sehingga suasana kelas menjadi ramai.

Hal ini seperti yang dikatakan MC. Donald motivasi adalah perubahan energi dalam diri seseorang yang ditandai dengan munculnya "feeling" dan didahului dengan tanggapan terhadap adanya tujuan. ${ }^{27}$ Motivasi adalah dorongan dasar yang menggerakan seseorang bertingkah laku. Dorongan ini berada pada diri seseorang yang menggerakan untuk melakukan sesuatu yang sesuai dengan dorongan dalam dirinya.

Berdasarkan uraian yang telah dikemukakan pada pembahasan di atas, maka sekiranya Islam menganjurkan umatnya agar senantiasa berusaha mencari ilmu pengetahuan di samping berusaha untuk meningkatkan kemahiran dan penguasaan diri dalam pelbagai bidang. Selain itu, ilmu pengetahuan juga merupakan kunci kepada kebahagiaan hidup manusia di dunia, karena sekiranya kita hidup tanpa ilmu, kemungkinan kita pada hari ini masih lagi berada dalam kemunduran dan kemiskinan. Oleh itu, jelaslah kepada kita bahwa ketinggian ilmu pengetahuan merupakan ukuran yang sangat penting dalam membedakan antara kemajuan dan kemunduran bagi sesuatu bangsa dan negara.

Apabila kita berbicara tentang ilmu dan pendidikan berarti sekaligus kita meletakkan para guru dan pendidik sebagai golongan yang amat 
penting sebagai agen pembangunan. Tugas seorang pendidik bukanlah satu tugas yang mudah dan bukan boleh dilakukan oleh semua orang. Justru itu, kerjanya sebagai seorang pendidik dianggap sebagai satu tugas yang sangat mulia dan istimewa. Lebih-lebih lagi dalam era yang penuh mencabar ini, menuntut pengorbanan dan komitmen yang padu dalam mendidik anak bangsa menjadi insan yang cemerlang, berwibawa dan sentiasa mendapat petunjuk serta keridhoan dari Allah. Karena itu, kita seharusnya bersyukur di atas pengorbanan dan jasa guru yang telah mendidik serta membimbing kita menjadi manusia yang baik pada hari ini. Baik guru yang terlibat secara langsung mendidik kita di sekolah maupun diperingkat universiti dan tidak kurang penting juga kepada guru yang mengajar kita mengenal membaca ayat-ayat al-Quran, ilmu fardhu ain dan sebagainya. Tanpa bimbingan dan tunjuk ajar dari mereka kita tidak mempunyai asas yang kuat untuk mengamalkan kefardhuan asas dalam Islam. Kita sedar bahwa ilmu yang ada pada diri kita ini sebenarnya hanyalah sedikit.

\section{KESIMPULAN}

Berdasarkan hasil penelitian dan pembahasan yang berkaitan dengan kompetensi pedadodik guru pendidikan agama islam dalam meningkatkan motivasi belajar peserta didik MA Nurul Ikhlas Ambon, dapat disimpulkan bahwa:

1. Kompetensi pedagogik guru PAI dalam proses pembelajaran di MA Nurul Ikhlas Ambon yakni pemahaman kepada peserta didik sudah sangat baik, hal ini dilihat dari beberapa hal diantaranya; a. Guru memberikan pemahaman terhadap peserta didik dalam aktivitas pembelajaran, b. Guru PAI dalam kegiatan pembelajaran mengacu pada perangkat pembelajaran yakni silabus dan RPP, c. guru PAI merancang pembelajaran, d. guru PAI memanfaatkan teknologi pembelajaran, e. guru PAI melakukan evaluasi setelah proses pembelajaran selesai, f. guru mengembangkan pengembangan potensi 
peserta didik dan g. guru PAI melakukan bimbingan konseling kepada peserta didik.

2. Motivasi belajar peserta didik di MA Nurul Ikhlas Ambon yaitu terlihat sangat baik karena dalam pembelajaran peserta didik sangat aktif dalam mengemukakan pendapat mereka, senang dalam mengikuti proses pembelajaran misalnya: respon terhadap pertanyaan guru serta teman sekelas dan jawaban peserta didik baik tepat atau tidak tetap dihargai sehingga mereka sangat senang serta termotivasi, senang memberikan pertanyaan maupun tanggapan, tepat dalam mengerjakan tugas dan tugas yang sudah dikerjakan dikumpul kemudian dikembalikan benar atau salah guru PAI selalu memberikan komentar baik lisan yang berupa kata-kata yang dapat memotivasi mereka dan untuk komentar tulisan hanya berupa benar salah, serta pendapat dari teman sekelas membuat mereka lebih termotivasi.

\section{SARAN}

Adapun saran yang penulis sampaikan, diantaranya:

1. Bagi kepala sekolah, agar selalu memperhatikan fasilitas sekolah dan memeriksa komponen-komponen pembelajaran guru-gurunya serta memenuhi kebutuhan guru seperti teknologi belajar agar tujuan pembelajaran yang diinginkan tercapai.

2. Bagi guru, agar selalu memperhatikan komponen-komponen mengajar dan menjalankan kompetensi pedagogiknya sebagai guru serta selalu meningkatkan motivasi belajar peserta didik.

\section{DAFTAR PUSTAKA}

[1] Abdul Majid \& Dian Andayani, Pendidikan Agama Islam Berbasis Kompetensi, (Cet. II; Bandung: PT Remaja Rosdakarya, 2005.

[2] Departemen Agama RI, Al-Qur'a dan Terjemahnya, (Semarang: Toha Putra, 2012. 
[3] Dewi Salma, Mozaik Teknologi Pendidikan E-learning (Cet. I; Bandung: Prenada Media Group, 2016.

[4] E. Mulyasa, Kurikulum Tingkat Satu Pendidikan, (Bandung: PT Remaja Rosdakarya,2007.

[5] E. Mulyasa, Standar Kompetensi dan Sertifikasi Guru (Bandung: Remaja Rosdakarya, 2010.

[6] Faridatul Ainiyah, Skripsi: Kompetensi Pedagogik Guru Dalam Meningkatkan Motivasi Belajar Bahasa Arab Siswa Madrasah Ibtidaiyah Darussalam Jawa Tengah (Yogyakarta: UIN Sunan kalijaga, 2014.

[7] Faridatul Ainiyah, Tesis: Kompetensi Pedagogik Guru Dalam Meningkatkan Motivasi Belajar Bahasa Arab Siswa Madrasah Ibtidaiyah Darussalam Jawa Tengah (Yogyakarta: UIN Sunan kalijaga, 2014.

[8] Hasbi As Shiddiqy, Mutiara Hadits, (Cet. I; Jilid VIII; Jakarta: Bulan Bintang, 2000.

[9] Kumandar, Penilaian Auntentik, (Cet. III; Jakarta: PT Raja Grafindo Persada, 2014.

[10] Lexy J. Moleong, Metodologi Penelitian Kualitatif, (Bandung: Remaja Rosdakarya, 2004.

[11] Matthew Miles dan A. Michael Huberman, Analisa data Kualitatif: Buku Sumber Tentang Metode-Metode Baru. (Cet. I; Jakarta: UI Press, 2002.

[12] Nana Syaodih Sukmadinata, Landasan Psikologi Proses Pendidikan, (Cet. III; Bandung: Remaja Rosdakarya.

[13] Novan Ardy Wiyani, Desain Pembelajaran Pendidikan, (Cet. I; Yogyakarta: Ar-Ruzz Media, 2013.

[14] Nur Uhbiyati, IImu Pendidikan Islam 2, (Bandung: CV. Pustaka Setia, 2002.

[15] Oemar Hamalik, Pendekatan Baru Strategi Belajar Mengajar Berdasarkan CBSA, (Cet. II; Bandung: Sinar Baru Algensindo 2001.

[16] Paul Suparno, Filsafat Konstruktivisme Dalam Pendidikan, (Cet. V; Yogyakarta: Penerbit Kanisius, 1997. 
[17] Sardiman A.M., Interaksi dan Motivasi Belajar Mengajar (Jakarta: Raja Grafindo Persada, 1996.

[18] Sardiman, Interaksi dan Motivasi Belajar Mengajar, (Jakarta: PT Raja Grafindo Persada, 2005.

[19] Standar Kualifikasi Akademik dan Kompetensi Guru (Menteri Pendidikan Nasional RI Nomor 16 Tahun 2007.

[20] Sugiyono, Metode Penelitian Kuantitatif dan Kualitatif dan $R \& D$, (Bandung: CV. Alfabeta, 2012.

[21] Undang-undang Guru dan Dosen, (UU No. 14 Tahun 2005.

[22] Undang-Undang Nomor 14 Tahun 2005 tentang Guru dan Dosen (Jakarta: Gema Insani Press, 2007.

\footnotetext{
${ }^{1}$ Nur Uhbiyati, IImu Pendidikan Islam 2, (Bandung: CV. Pustaka Setia, 2002), hlm. 13.

2 E. Mulyasa, Standar Kompetensi dan Sertifikasi Guru (Bandung: Remaja Rosdakarya, 2010), hlm. 5.

3 Undang-Undang Nomor 14 Tahun 2005 tentang Guru dan Dosen (Jakarta: Gema Insani Press, 2007), hlm.16.

${ }^{4}$ Faridatul Ainiyah, Skripsi: Kompetensi Pedagogik Guru Dalam Meningkatkan Motivasi Belajar Bahasa Arab Siswa Madrasah Ibtidaiyah Darussalam Jawa Tengah (Yogyakarta: UIN Sunan kalijaga, 2014), hlm. 17.

5 Standar Kualifikasi Akademik dan Kompetensi Guru (Menteri Pendidikan Nasional RI Nomor 16 Tahun 2007), hlm. 75.

6 Sardiman, Interaksi dan Motivasi Belajar Mengajar, (Jakarta: PT Raja Grafindo Persada, 2005), hlm. 75.

${ }^{7}$ Observasi di MA Nurul Ikhlas Ambon tanggal 29 Agustus 2019.

8 Sufyan A. Kaur Kurikulum MA Nurul Ikhlas Ambon, wawancara tanggal 29 Agustus 2019

${ }^{9}$ Lexy J. Moleong, Metodologi Penelitian Kualitatif, (Bandung: Remaja Rosdakarya, 2004), hlm. 45.

${ }^{10}$ Sugiyono, Metode Penelitian Kuantitatif dan Kualitatif dan $R \& D$, (Bandung: CV.

Alfabeta, 2012), hlm. 240.

${ }^{11}$ Sugiyono, Metode Penelitian Kuantitatif dan Kualitatif dan R \& D, hlm. 246

12 Matthew Miles dan A. Michael Huberman, Analisa data Kualitatif: Buku Sumber Tentang Metode-Metode Baru. (Cet. I; Jakarta: UI Press, 2002), hlm. 29.

${ }^{13}$ Hasbi As Shiddiqy, Mutiara Hadits, (Cet. I; Jilid VIII; Jakarta: Bulan Bintang, 2000), hlm. 26.

${ }^{14}$ Departemen Agama RI, Al-Qur'a dan Terjemahnya, (Semarang: Toha Putra, 2012), hlm. 59.

${ }^{15}$ Faridatul Ainiyah, Tesis: Kompetensi Pedagogik Guru Dalam Meningkatkan Motivasi Belajar Bahasa Arab Siswa Madrasah Ibtidaiyah Darussalam Jawa Tengah (Yogyakarta: UIN Sunan kalijaga, 2014), hlm. 17.

${ }^{16}$ E. Mulyasa, Kurikulum Tingkat Satu Pendidikan, (Bandung: PT Remaja

Rosdakarya,2007), hlm. 33.

17 lbid., hlm. 213.

${ }^{18}$ Undang-undang Guru dan Dosen, (UU No. 14 Tahun 2005), hlm. 16.
} 
${ }^{19}$ Dewi Salma, Mozaik Teknologi Pendidikan E-learning (Cet. I; Bandung: Prenada Media Group, 2016), hlm. 26.

${ }^{20}$ Abdul Majid \& Dian Andayani, Pendidikan Agama Islam Berbasis Kompetensi, (Cet. II; Bandung: PT Remaja Rosdakarya, 2005), hIm. 88.

${ }^{21}$ Novan Ardy Wiyani, Desain Pembelajaran Pendidikan, (Cet. I; Yogyakarta: Ar-Ruzz Media, 2013), hlm. 178-180.

22 Kumandar, Penilaian Auntentik, (Cet. III; Jakarta: PT Raja Grafindo Persada, 2014), hlm. 339.

${ }^{23}$ Ibid, hlm. 39.

${ }^{24}$ Paul Suparno, Filsafat Konstruktivisme Dalam Pendidikan, (Cet. V; Yogyakarta:

Penerbit Kanisius, 1997), hlm. 61.

${ }^{25}$ Oemar Hamalik, Pendekatan Baru Strategi Belajar Mengajar Berdasarkan CBSA, (Cet. II; Bandung: Sinar Baru Algensindo 2001), hlm. 4.

${ }^{26}$ Nana Syaodih Sukmadinata, Landasan Psikologi Proses Pendidikan, (Cet. III; Bandung: Remaja Rosdakarya), hIm. 158.

${ }^{27}$ Sardiman A.M., Interaksi dan Motivasi Belajar Mengajar (Jakarta: Raja Grafindo Persada, 1996), hlm. 74. 